Santa Clara University

Scholar Commons

Psychology

College of Arts \& Sciences

2-7-2008

\title{
The development of the Santa Clara Brief Compassion Scale: An abbreviation of Sprecher and Fehr's Compassionate Love Scale
}

Jeong Yeong Hwang

Thomas G. Plante

Santa Clara University, tplante@scu.edu

Kathleen Lackey

Follow this and additional works at: http://scholarcommons.scu.edu/psych

Part of the Psychology Commons

\section{Recommended Citation}

Hwang, J. Y., Plante, T. G., \& Lackey, K. (2008). The development of the Santa Clara Brief Compassion Scale: An abbreviation of Sprecher and Fehr's Compassionate Love Scale. Pastoral Psychology, 56, 421-428.

The final publication is available at Springer via http://doi.org/10.1007/s11089-008-0117-2

This Article is brought to you for free and open access by the College of Arts \& Sciences at Scholar Commons. It has been accepted for inclusion in Psychology by an authorized administrator of Scholar Commons. For more information, please contact rscroggin@scu.edu. 
The Development of the Santa Clara Brief Compassion Scale: An Abbreviation of Sprecher and Fehr's Compassionate Love Scale

\author{
Jeong Yeon Hwang, Thomas Plante, Katy Lackey ${ }^{1}$
}

Psychology Department, Santa Clara University, Santa Clara, California. Address correspondence to Thomas G. Plante, Psychology Department, Santa Clara University, Santa Clara, CA. 95053-0333; Email: tplante@ @scu.edu; Telephone: 408-554-4471.

\footnotetext{
${ }^{1}$ Psychology Department, Santa Clara University, Santa Clara, California. Address correspondence to Thomas G. Plante, Psychology Department, Santa Clara University, Santa Clara, CA. 95053-0333; Email: tplante@scu.edu; Telephone: 408-554-4471.
} 